\title{
Time-course Alteration of Lipoxygenase Activity in Blast-infected Rice Leaves
}

\author{
Tsuneo NamaI*, Tadahiro Kato**, Yoshihiro YamaguchI*** \\ and Jiro Togash *
}

\begin{abstract}
To reveal the relationship between the resistance to rice blast disease on rice plants and the amount of oxygenated $\mathrm{C}_{-18}$ unsaturated fatty acids isolated from rice plant as antiblast substances, the change of the activity of lipoxygenase (LOX) which participates in the synthesis of these compounds in rice leaves was investigated. Although LOX activity in rice leaves was sensitive to the water-spraying resulted in a little increment, it has been clearly and largely enhanced by blast infection. The pattern of change in LOX activity with days after inoculation depended on the combination of rice cultivar and the race of rice blast fungus. In rice leaves shown incompatible reaction, LOX activity increased rapidly from the first day of spray-inoculation and reached to the maximum two or three days after, and declined thereafter. In the compatible combination, the highest activity was observed seven days after inoculation, although LOX activity rose temporarily in two or three days. Rice cultivars having higher level of field resistance showed higher LOX activity than that with low level of it. In addition, LOX activity in mature leaves was also greater than that of the just expanded young leaves of all cultivars examined.
\end{abstract}

(Received August 8, 1989)

Key words: lipoxygenase activity, blast-infected rice leaves, Pyricularia oryzae Cavara.

\section{INTRODUCTION}

In the previous studies ${ }^{6-8)}$, the authors isolated some kinds of derivatives of oxygenated $\mathrm{C}_{-18}$ unsaturated fatty acids from rice plants as anti-blast substances on searching the phytoalexin of rice plant. It is easily assumed that allyl alcohols of fatty acids are metabolized primarily via hydroperoxides of the $\mathrm{C}_{-18}$ unsaturated fatty acids produced by enzyme reaction of LOX in rice plant. Formerly, when the rice tissues have pre-treated with salcilhydroxamic acid or $n$-propyl gallate both of which are known as inhibitory agents to LOX activity, the authors have observed the conversion phenomenon from resistant reaction to susceptible one in epidermal cells of detached rice sheath by inoculation with incompatible race of rice blast fungus ${ }^{10}$. It seems plausible from our and also other ${ }^{9)}$ findings, that the peroxides and their derivatives play an important role on the manifestation of resistant reaction at the site of blast infection on rice plant.

The purpose of this study was to examine the change in LOX activity in rice leaves inoculated with incompatible or compatible race of this fungus, Pyricularia oryzae Cavara and timecourse alteration of the enzyme activity with the advance of a rice leaf age.

* Faculty of Agriculture, Yamagata University, Wakaba-machi 1-23, Tsuruoka-shi, Yamagata 997, Japan 山形大学農学部

** Department of Chemistry, Science University of Tokyo, Kagurazaka 1-3, Shinjyuku-ku, Tokyo 162, Japan 東京理科大学理学部

*** Department of Chemistry, Kinki University, Kowakae 3-4-1, Higashi-Osaka-shi, Osaka 577, Japan 近畿大学理工学部 


\section{MATERIALS AND METHODS}

Rice plant. Four rice cultivars, Aichiasahi, Homarenishiki, Fukuyuki and Yoneshiro, were used in this experiment. The former two cultivars have a true resistance gene $P i$ - $a$ and the latter two cultivars have the gene $P i-i$ to rice blast disease. Aichiasahi and Fukuyuki show the low level of field resistance, whereas Homarenishiki and Yoneshiro are cultivars having the high level of field resistance to rice blast disease.

Fungus. Two kinds of isolates, F $67-54$ and TH $67-22-\mathrm{V}$ of rice blast fungus maintaining in the author's laboratory (Yamagata University), were used. The isolate F 67-54 (race 047) is compatible with all the cultivars examined. However, another isolate TH 67-22-V (race 031) is incompatible with these cultivars.

Inoculation. Germinated rice seeds were sown on seedling case $(5 \times 15 \times 10 \mathrm{~cm})$ containing sandy soil with $2 \mathrm{~g}$ of fertilizer (Katakura Tikkarin, 10-12-10) and placed in an air-controlled green house $(25 \pm 2 \mathrm{C})$ until the 8 th leaf expanded completely. The rice plants were sprayinoculated with the suspension of conidia $\left(10^{5}\right.$ conidia $\left./ \mathrm{ml}\right)$ which were produced on the oatmeal agar medium by usual ways ${ }^{11}$. After spraying, the rice plants were maintained in a moist chamber at $25 \mathrm{C}$ for $24 \mathrm{hr}$. After incubation, the rice plants were transferred to another aircontrolled green-house $(25 \pm 2 \mathrm{C})$ and grown for 10 days. Rice plants sprayed with deionized water were used as control.

Sampling of rice leaves. For measurement of the change in LOX activity, rice leaves were sampled at $0,1,2,3,5$, and 7 th day after inoculation. LOX activity in young and mature leaves were assayed at the 7 th and 6 th leaves in the emergence stage of the 8 th leaf, respectively. The harvested rice leaves were wrapped with aluminum foil and stored at $-30 \mathrm{C}$ in a freezer for the experiment use.

Measurement of lipoxygenase activity. The method for measurement of LOX activity is shown in Fig. 1. Namely, $0.5 \mathrm{~g}$ of rice leaves was frozen in liquid $\mathrm{N}_{2}$ and ground with a pestle and mortar. The powdered rice leaves were homogenized with $5.0 \mathrm{ml}$ of MacIlvaine buffer ( $\mathrm{pH}$ 6.4). The homogenate was filtrated through 4 layers of gauze, and the filtrate was used for the present study. Two $\mathrm{ml}$ of the filtrate was added to the same volume of linolenic

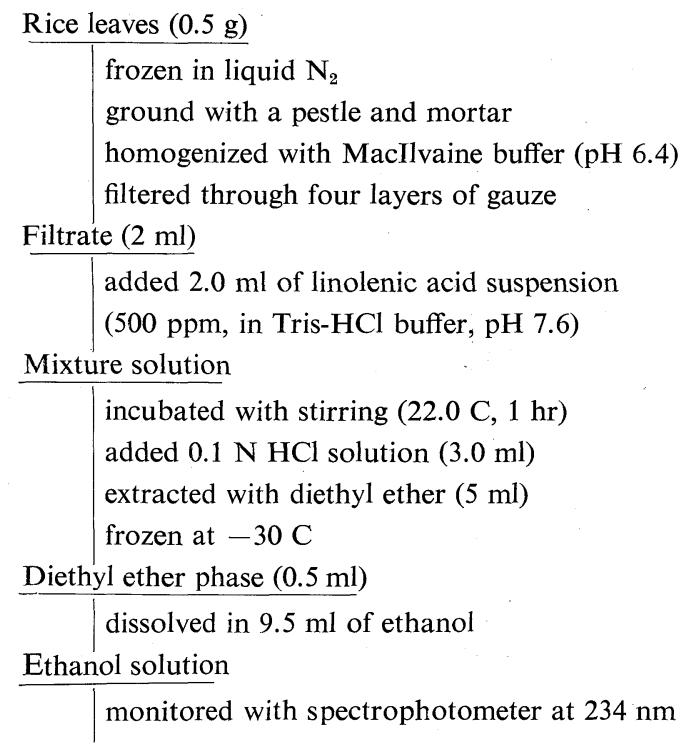

Fig. 1. Procedure for measurement of lipoxygenase activity in rice leaves. 
acid suspension $(0.5 \%$ of $0.1 \mathrm{M}$ Tris-HCl buffer containing a trace of Tween $80, \mathrm{pH} 7.4)$ and the mixture was incubated at $22 \mathrm{C}$ for $1 \mathrm{hr}$ with stirring. After incubation, $3.0 \mathrm{ml}$ of $0.1 \mathrm{~N} \mathrm{HCl}$ was added to the reaction mixture to quench the further enzyme reaction and extracted with diethyl ether directly. Then, the extracted solution was frozen at $-30 \mathrm{C}$ to isolate the ether phase from the emulsioned mixture. After warming the frozen mixture to room temperature, $0.5 \mathrm{ml}$ of ether phase was picked up and added to the $9.5 \mathrm{ml}$ of ethanol. The alcoholic solution was monitored with a spectrophotometer (Hitachi U-3210) at $234 \mathrm{~nm}$.

\section{RESULTS}

\section{Lipoxygenase activity in rice leaves inoculated with rice blast fungus}

An absorption curve having a maximum peak at $234 \mathrm{~nm}$ and small shoulder near the 270 $\mathrm{nm}$ was obtained in the case of the Aichiasahi leaves at 7 th day after inoculation with compatible race, F67-54. However, there was a slight absorption peak at $234 \mathrm{~nm}$ in the enzyme reaction using the rice leaves of the same cultivar treated with water-spraying (Fig. 2). Since the peak at the $234 \mathrm{~nm}$ was due to the presence of conjugated diene chromophore in hydroperoxides of $\mathrm{C}_{-18}$ unsaturated fatty acids, it is reasonable to estimate the degree of LOX activity by the height of this peak. Thus, it was shown that the LOX activity in rice leaves increased by infection with rice blast fungus.

\section{Time-course alteration of lipoxygenase activity in young leaves of rice}

Time-course of change in LOX activity after inoculation to the just expanded young leaves, 7th leaves in the 8-leaf-emergence stage of two rice cultivars possessing a true resistance gene $P i-a$ is shown in Fig. 3. The (A) in this figure shows the change in the enzyme activity in Aichiasahi leaves and the (B) indicates that of Homarenishiki. It is evident that differences in the pattern of the enzyme activity are observed between the combinations of the rice cultivar and race of this fungus. In the compatible combination the enzyme activity enhanced gradually until three days after inoculation, thereafter decreased slightly, and then increased again at 7 th day after inoculation in both rice cultivars commonly. On the other hand, LOX activity in the incompatible combination enhanced rapidly at the just after inoculation, and the enhancement

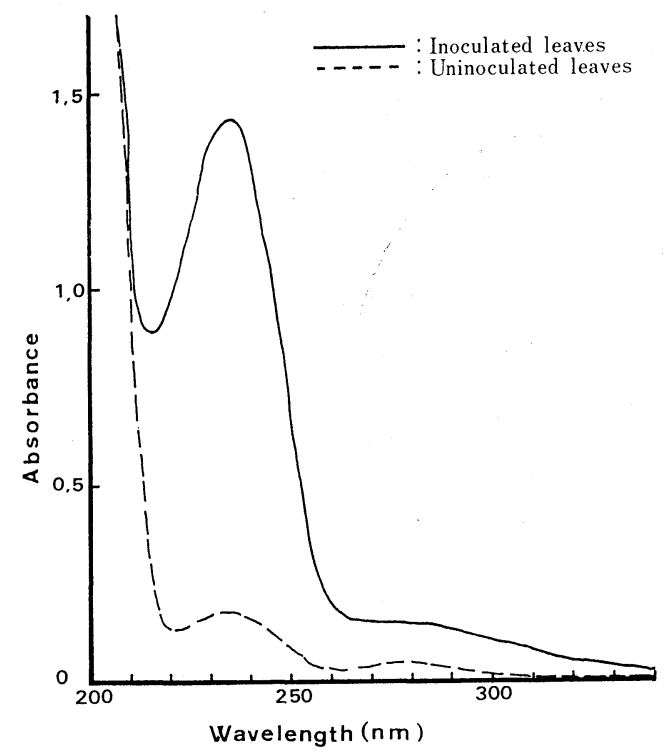

Fig. 2. Absorption curve of enzyme products. 
continued for three days, thereafter declined gradually. But, the re-increase of this enzyme activity was not observed. The LOX activity of rice cultivar with high level of field resistance such as Homarenishiki was relatively greater than that of cultivar with low level of field resistance, Aichiasahi in each combination.

Time-course of change in LOX activity in rice leaves of two rice cultivars having a true resistance gene Pi-i is shown in Fig. 4. The (A) exhibits the change in the enzyme activity in Fukuyuki leaves and the (B) indicates that of Yoneshiro leaves, respectively. The pattern of change in LOX activity on each combination resembled to that of the rice cultivars with Pi-a gene (Fig. 3). Also, the degree of the enzyme activity in the rice leaves of the Yoneshiro, with high level of field resistance was higher than that of Fukuyuki with low level of it.

\section{Change in lipoxygenase activity in mature rice leaves}

Time-course of change in LOX activity in the mature leaves, 6th leaves in the 8-leaf-emergence stage, of two rice cultivars with a true resistant gene $P i-a$ is shown in Fig. 5. It is noticeable that the LOX activity in water-sprayed rice leaves of both rice cultivars increased considerably. The degree of the enzyme activity in mature rice leaves was higher than that of young leaves, although each pattern of the enzyme activity among these combinations was similar to those of the young leaves in each case (Fig. 3). Strictly speaking, however, the LOX activity in compatible Aichiasahi leaves at the first day after inoculation was rather lower than that of water-sprayed. In Homarenishiki leaves, degree of LOX activity in the compatible combination was remarkably higher than that of Aichiasahi leaves. However, in the incompatible combination the time-course alteration of this enzyme activity showed the similar pattern to that of water-sprayed leaves of the same rice cultivar.

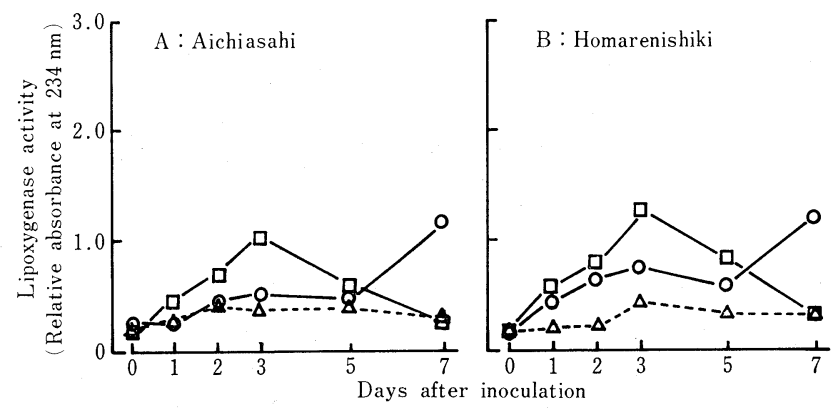

Fig. 3. Time-course of changes in lipoxygenase activities in young leaves of two rice cultivars having a true resistance gene Pi-a. $\square$, incompatible combination; $\bigcirc$, compatible combination; $\triangle$, control (water-spraying).

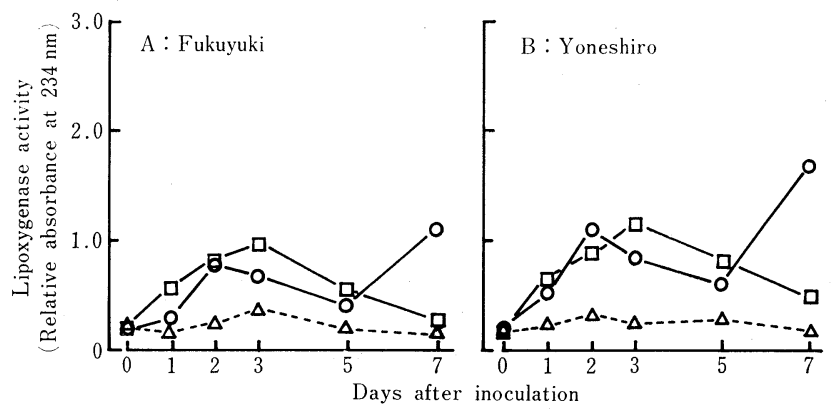

Fig. 4. Time-course of changes in lipoxygenase activities in young leaves of two rice cultivars having a true resistance gene $P i-i$. $\square$, incompatible combination; $\bigcirc$, compatible combination; $\triangle$, control (water-spraying). 


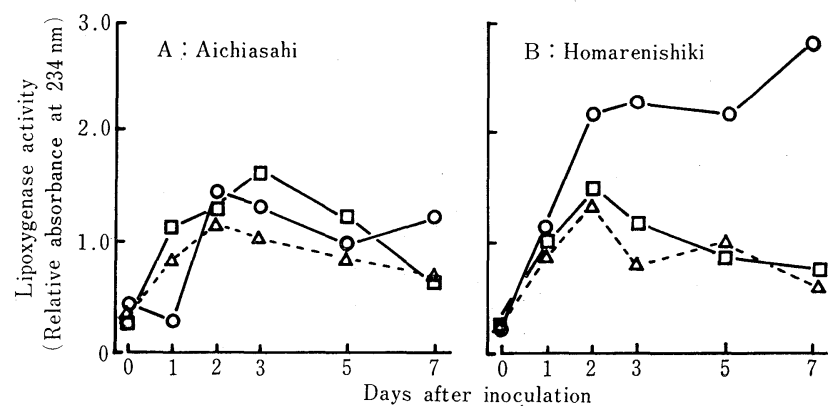

Fig. 5. Time-course of changes in lipoxygenase activities in mature leaves of two rice cultivars having a true resistance gene $P i-a . \quad \square$, incompatible combination; $\bigcirc$, compatible combination; $\triangle$, control (water-spraying).

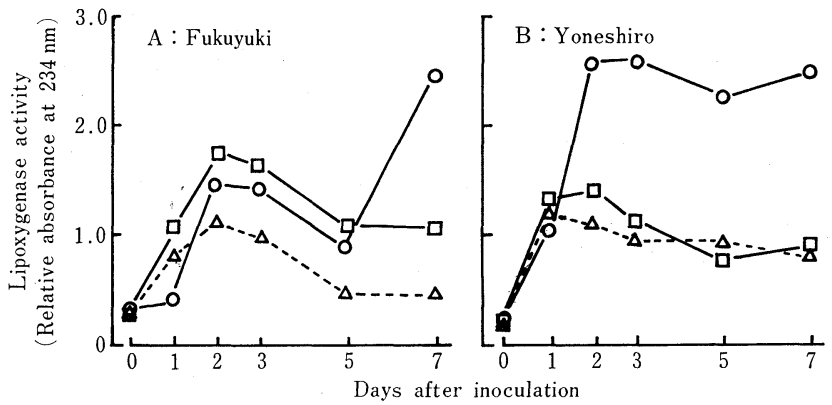

Fig. 6. Time-course of changes in lipoxygenase activities in mature leaves of two rice cultivars having a true resistance gene Pi-i. $\square$, incompatible combination; $\bigcirc$, compatible combination; $\triangle$, control (water-spraying).

Figure 6 shows the time-course of change in LOX activity in the mature leaves of two rice cultivars possessing a true resistance gene Pi-i. The pattern of the enzyme activity of rice cultivars in each combination was similar to that of the rice cultivars with a Pi-a gene (Fig. 4). Moreover, it is also recognized that the enzyme activity in Fukuyuki leaves inoculated with compatible race was reduced at first day after inoculation in comparison with the water-sprayed leaves of the same cultivar. On the other hand, Yoneshiro with high level of field resistance indicated by far the highest LOX activity in the compatible combination than that of Fukuyuki with low level of field resistance. In the incompatible combination, the pattern of LOX activity was similar to that in water-sprayed leaves.

\section{DISCUSSION}

There are some reports dealing with the change in LOX activity in the plants infected with plant pathogenic virus ${ }^{5}$, bacterium ${ }^{2}$ and fungus ${ }^{11)}$. Furthermore, the occurrence of lipid peroxidation on infected plants was also demonstrated by many workers ${ }^{3,4,9)}$. In this paper, we investigated the change in LOX activity in rice leaves infected with compatible and incompatible races of rice blast fungus, Pyricularia oryzae. There are many kinds of methods for measuring of LOX activity, but our method designed in the previous work $\left.{ }^{6-8}\right)$ was used here. The authors confirm that there are some advantages in this method. For example, it is convenient to carry out because the filtrate of homogenized rice leaves can be immediately used as enzyme preparation without any procedure for purification. In addition, since the enzyme products can be easily 
extracted without loss of the bioactivity, the hydroperoxides of $\mathrm{C}_{-18}$ unsaturated fatty acids can be subjected to bioassay.

The pattern of change in LOX activity in the inoculated rice leaves was different between the combinations of rice cultivar and race of rice blast fungus. It is also altered among the cultivars with the different level of field resistance. And it is clear that the enzyme activity varied with the maturity of the leaf even in the same rice plant.

It is well known that the process of the lesion formation on inoculated rice leaf was different among the cultivar-race combinations. In the incompatible combination, many small brown lesions appear on the rice leaves at two or three days after inoculation. However, neither number nor size of the lesion increases by further incubation of the day when the resistant lesion appeared. On the contrary, in the compatible combination, susceptible lesions appear on the leaf at the 4th or 5th day after inoculation and the lesion enlarges with elapsing time, although the resistant brown lesion have already occurred on the same leaf. Finally, the susceptible grayish lesion becomes to be encircled with brownish necrotic zone at the 7 th day after inoculation.

On the rice cultivar with high level of field resistance, the number of resistant lesion appeared on the leaves inoculated with compatible race was relatively greater than that of rice cultivar with low level of field resistance. While, on the 6th leaf of 8-leaf stage of rice plant infected with compatible race, the percentage of resistant lesion and the brownish zone encircled grayish susceptible lesion are higher and broader than those of 7 th leaf occurred even in the same rice cultivar. Especially, on the 6th leaves of rice cultivars possessing high level of field resistance, even the resistant brown lesion do not always appeared when the incompatible race is sprayed.

Based on these facts, it is clear that the change in the alteration of LOX activity in rice leaves was closely related to the appearance of the brown lesion or brownish zone encircled with susceptible lesion on rice leaf. Therefore, it may be considered that the early enhancement of this enzyme activity was due to the appearance of resistant brown lesion before the susceptible lesion was appeared and that the latter increment of the enzyme activity depended on the formation of the encircled brownish zone around the susceptible lesion in the compatible combination. In the incompatible combination, it seems plausible that the latter enhancement of the LOX was not observed, because of the susceptible lesion with brownish zone is not formed.

Since the increase of enzyme activity is correlated with the amount of enzyme products, it may be evidenced that the appearance of the resistant reaction to rice blast fungus is closely related with the amount of enzyme products, oxygenated $\mathrm{C}_{-18}$ unsaturated fatty acids in the rice leaves.

It is interesting that a small enhancement of LOX activity in water-sprayed mature rice leaves was observed. However, the same increment was not always detected in young leaves. This indicates that the LOX activity might be likely altered sensitively by the external conditions and that the degree of the sensitivity might be related with the maturity of a leaf. On the other hand, in two rice cultivars, Aichiasahi and Fukuyuki with low level of field resistance, it was noticed that the LOX activity in mature leaves at the first day after inoculation of compatible race was rather suppressed than the leaves water-sprayed. This phenomenon demonstrated that there were unknown suppressing factors to LOX activity at the early infection in compatible combination.

\section{Literature cited}

1. Furuta, T. and Sekiguchi, Y. (1967). Plant Protection 21: 160-162.

2. Kepper, L.D. and Novacky, A. (1987). Physiol. Molec. Plant Pathol. 30: 233-245.

3. Kepper, L.D. and Novacky, A. (1986). Phytopathology 76: 104-108.

4. Kato, S. and Misawa, T. (1976). Ann. Phytopath. Soc. Japan 42: 472-480.

5. Kato, S. (1977). Tohoku J. Agr. Res. 28: 1-7. 
6. Kato, T., Yamaguchi, Y., Uyehara, T., Yokoyama, T., Namai, T. and Yamanaka, S. (1983). Naturwissenchaften 70: 200-201.

7. Kato. T., Yamaguchi, Y., Uyehara, T., Yokoyama, T., Namai, T. and Yamanaka, S. (1983). Tetrahedron Lett. 24: 4715-4718.

8. Kato, T., Yamaguchi, Y., Hirano, T., Yokoyama, T., Uyehara, T., Namai, T., Yamanaka, S. and Harada, N. (1984). Chem. Lett. 409-412.

9. Matsuyama, N. (1983). Ann. Phytopath. Soc. Japan 49: 270-273.

10. Tomita, H., Yamanaka, S., Namai, T. and Kato, T. (1984). Ibid. 50: 107 (Abstr.).

11. Yamamoto, H. and Tani, T. (1986). J. Phytopathol. 116: 329-337.

\section{和 文 摘 要}

生井恒雄・加藤忠弘・山口亿宏・富樫二郎：いもち病感染イネ葉におけるリポキシゲナーゼ活性の変動

イネより抗いもち病菌物質として抽出された酸化型 $\mathrm{C}_{-18}$ 不飽和脂肪酸のいもら病に対するイネの抵抗性 との関係を検討する研究の一つとして，感染葉に牧けるリポキシゲナーゼ (LOX) 活性の変動を調べた。 LOX 活性は, 8 葉展開期のイネの第 7 葉および第 6 葉についてイネいもち病菌分生胞子懸濁液の噴霧接種 後, 経時的に測定した。LOX 活性は水噴霧でも敏感に変動したが，いもち病菌接種により明らかに増高し た。LOX 活性の変動パターンはイネ品種とイネいもら病菌レースとの組合せにより異なった。非親和性の 組合せでは接種後 1 日目から LOX 活性が急激に増加し，3 日目に最大となるが以降は低下した。これに対 して親和性の組合せでは，接種後 2 3 日目に一時的に増加したが， 7 日目に最大となった。また，直場抵 抗性の強い品種は弱い品種より LOX 活性の増高がより明確となる傾向がみられた。さらに, 同一品種にお いて成熟葉の LOX 活性が展開直後の若い葉のそれより高い傾向が共通して認められた。 